\title{
Thoughts Behaviors of Parents on Motivating Their Children Aged 4-6 for Music
}

\author{
İlknur Özal Göncü \\ Correspondence: İlknur Özal Göncü, Gazi University, Gazi Education Faculty, Division of Music Education, Turkey.
}

Received: June 5, 2018

doi:10.11114/jets.v6i9.3340
Online Published: July 9, 2018

URL: https://doi.org/10.11114/jets.v6i9.3340

\begin{abstract}
The aim of this study is to identify the thoughts and behaviors of parents in motivating their children aged 4-6 for music, and for a hobby or profession related to music.

While collecting the qualitative data for the study, literature review model has been used. For the collection of the quantitative data, on the other hand, a questionnaire has been applied to the parents of children. Collected data has been processed on SPSS and displayed in tables consisting of frequency (n) and percentage (\%) values.

Population of the research consists of the parents of children enrolled to the preschools affiliated to the official primary schools of Ministry of Education, located in the center of Ankara. The sample of the research, on the other hand, consists of 150 parents of children aged 4-6, who were enrolled to a total of 10 official preschool education institutions in the 2017-2018 school year, affiliated to the Ministry of Education and located in in the center of Ankara. The sample group has been determined through random sampling method. Findings of the study mainly reveal that; even though the parents encourage their children to listen to music, sing and engage in music most of the time, they do not want their children to choose a profession related to this field.
\end{abstract}

Keywords: preschool education, music education, preschool music education, parents' thoughts, parents' behaviors

\section{Introduction}

Music is a form of art that enables us to express our feelings and thoughts through sounds. Music is simply "an aesthetic combination of sounds brought and processed together with the sense of beauty, based on a particular purpose and method. With the help of music, the interaction of the individual with the environment, especially the musical environment, becomes healthier, more regular, effective and productive" (Uçan, 1997).

According to Sun, music education has a cultural significance, too. A society may continue its existence with the help of the avant-garde values created in the fields of economics and culture, and contributing to the social life. Music is a branch of this cultural values. Continuity of a society in this field is only possible by means of integrating appropriate music to their lives. The society can only maintain its musical existence as long as these are achieved; otherwise, it is hardly possible (Sun \& Seyrek, 1993).

As a branch of art and science, music is an effective part in the process of an individual's growth. It has a power which may directly influence people's behaviors. A person becomes happy, sad, calm or aggressive depending on the type of music listened to.

Introduction of a baby with the sounds starts indirectly in their mothers' womb, and directly with the environment that the baby faces once s/he is born. In time, the baby becomes able to distinguish, perceive and interpret the musical and non-musical sounds present in the natural, social and cultural environment. This relationship with music exists in every aspect of life and lasts until death (Göncü, 2016).

The famous Hungarian music scholar Kodaly once said: "I used to think that the musical education of a child must start nine months before his/her birth. I am no longer in favor of this idea. Musical education of children must start nine months before the mother's birth". With this, he emphasized the proposition that everybody must receive music education in order to be better and happier individuals (Öz, 2001).

According to Temiz (2007), children's acquisition of necessary musical skills, the discovery of their musical potential, and motivation for music depends on the environment they live in. Following the family, the first educational environment children face is the preschool institutions. With the help of the educational process here, psychomotor, 
self-care, and social, emotional, cognitive and linguistic development of the children are supported.

Music education paves the way for a child to enrich his/her world; such as listening and hearing actively, spiritual nourishment by means of appealing to his/her imagination, and canalizing to creativity. It is also suggested that in addition to developing skills, music education has an impact on children's cognitive achievements.

Studies show that the cognitive intelligence of children who play an instrument at an early age is more sustainable (Schlaug, Norton, OVery \& Winner, 2005).

Şendurur and Barış explain the impact of music education on children's cognitive achievements as: "Music education supports the development of academic and personal skills; such as the acquisition of critical thinking, problem-solving and the cooperative tasking in line with these purposes. It provides the hand-eye coordination in the child, recognition of rhythm and symbols, attention and other norms of the human mind" (Barış\& Şendurur 2002).

Music is a branch of art that appeals to all children. Singing, making sounds by means of knocking on something or dancing are actions naturally performed by children.

In child education, bringing up a child and preparing him/her for the society requires constant care since the beginning, mutual interaction, appreciation, time allocation, provision of welfare, nutrition and protection, and responding to his/her need for love. A mother who spends every minute of the day with her child and fulfils all these aforementioned is regarded to play an active role in the education of the child. The process of education which starts in the mother's womb, continues with the mother's interaction with the child after s/he is born, as the mother is the initial educator. Children perceive and interpret the sounds they hear as of their birth or even their formation better in time. Their process of musical development starts with distinguishing musical sounds (Göncü, 2002).

For a better musical playing, Suzuki assigned the task of preparing the physical and emotional environment for children to teachers and parents; as well as performing the activities with them. Family is of great importance in terms of applying the principles of ear-training and gradual skill acquisition. The family is responsible for teaching music to the child; just as teaching how to speak. Therefore, the family is supposed to turn the domestic environment into a "learning environment". In Suzuki method, family's participation in every lesson forms the basis for the mother-tongue approach. Mothers in particular, are required to watch all the lessons of the child actively and take notes (Kasap, 2005).

For a permanent learning, all the activities must be revised every day regularly. Here, family plays a significant role. Since children spend most of their time with their parents, they must arrange activities that influence their children's motivation so as to gain success. Suzuki stated that parents must fulfil a certain training in order to help their children more effectively (Kara \& Pirgon, 2013).

\section{The Significance of Music in Preschool Education}

Physical development of a child is a natural period. Musical education, on the other hand, develops only if the existing skill is accompanied by conscious and regular music education. Such an education, which starts with the musical activities in preschool period, has a direct impact on the child's future interest, knowledge, and skill in music. Given that learning is faster and more permanent in early ages, a proper music education offered in preschool period will provide the child with the habit of true and quality music listening, singing and playing.

In preschool education, rhythm and musical activities should not be based on singing and listening only. Children must be also encouraged to play instruments. All these activities lead to the child's ability to express emotions through music. According to the scientists, child prodigies or untalented children are regarded as exceptions; and those who are not within this classification are accepted to have talent in music somehow. In an early and right age and with the right environment and methods, every child can be educated through music. One of the most prominent supporters of this idea is the Japanese violinist and tutor Suzuki. 'The Suzuki Teaching Method' is based on a significant principle on talent. According to this principle, all children can learn music the same way they acquire their mother tongue, as long as they are supported with an environment appropriate for domestic and social growth (Arslan, 2003).

Following the school and teachers, parents are the most important factors in the education of children. Since the family support is crucial in music education, parents must be informed on their children's musical interests and skills and their awareness must be raised by the teachers. Studies show that music education has a positive impact on the development of a child in every aspect. Therefore, starting the music education in early ages requires the approval of parents who are supposed to provide this ground for their children.

In addition to all these, there are various music teaching methods developed for early childhood; such as Kindermusik, Kindyroo, Gymboree, Music Together etc. There are different programs defending the idea that the 
best learning starts once you leave the class, and that the family must be in cooperation in order to support the child's musical and developmental skills. Starting from this point of view, Music Together developed its understanding based on Edwin Gordon's theory of musical learning. Its origins date back to the Centre for Music and Young Children, which was established in 1985 by a composer named Kenneth K. Guilmartin with the purpose of creating a music-movement experience through parents-children. In order to attract attention to the importance of music in early childhood, Guilmartin observed the benefits of parents' participation in the educational process of their children; and he collaborated with Edwin Gordon and his students, who was pursuing studies on the tonal and rhythmic development in small children. As a result, he conducted studies with one of Gordon's students, named Lili M. Levinowitzv, and developed a program in an attempt to provide musical thinking skill for individuals and contribute to their lives with the help of music (cit. Özeke, 2017).

Artistic skills which reveal themselves as in music or painting require field-specific competencies, as well. These can be evaluated only with a healthy preliminary or early education. An educator who is willing to understand the skills of children may consider their experiences while learning in pre-school or elementary school period; and develop a better understanding by looking at the subjects they learn faster and easier or have difficulties in comprehending. Such an approach will enable the early discovery of children who may lean to special music education as a profession or a social activity (even if there is no professional concern) (Eskioğlu, 2003).

Problem of the study can be identified as the 'opinions and behaviors of parents on motivating their preschooler children aged 4-6 to for music'. Within this framework, the following questions are sought for answers.

1)What are the profiles of the parents of children aged 4-6 according to gender, age and education level?

2)How do the parents of children aged 4-6 approach towards the idea of their children's interest in music in daily life?

3)How supportive are the parents of children aged 4-6 in terms of encouraging their children's propensity for music?

With this in mind, the study aims to identify the positive and negative thoughts and behaviors of parents on motivating their preschooler children aged 4-6 for music. By doing so, the purpose is to contribute to the awareness of the parents of children in preschool education on the importance of music. The study is considered significant in terms of focusing on the musical education status of children aged 4-6.

\section{Method}

This is a descriptive study where general survey model has been utilized. In addition to that, the quantitative data obtained through survey method have been provided in tables.

Population of the research consists of the parents of children enrolled to the preschools affiliated to the state and private primary schools of Ministry of Education, located in the center of Ankara. Within this context, the number preschools operating within Çankaya district of Ankara province is 230 (https://oku.com.tr/anaokulu).

13 of them operate as state schools affiliated to the Ministry of Education. The other 217 are private institutions. Among these, a total of 10 schools, located in different regions of Çankaya, have been selected randomly. In terms of economic, educational and cultural backgrounds, families from low, medium and high levels have been particularly selected in order for the sampling to project population. All the schools are state schools. The other three schools were excluded due to not obtaining the approval of their principals. The sample of the research, on the other hand, consists of the parents of children aged 4-6, who were enrolled to a total of 10 preschool education institutions in 2017-2018 school year, affiliated to the Ministry of Education and located in in the center of Ankara. The sample group has been determined through a random sampling method.

The data have been collected through the questionnaire developed for this study. The questionnaire has been applied to the parents of children who study at preschool education institutions affiliated to the Ministry of Education.

Collected data have been evaluated with appropriate statistical methods after their percentage and frequency values are found, and analyzed on SPSS program.

More than half of the participants consist of mothers. The age group of the participants are mostly intensified between 31-35, and almost half of them stated to have finished university.

The questionnaire consists of a total of 15 questions. The questions seek for answers to the gender, age, educational background and ages of children, in an attempt to analyze the structure of the sampling. The number of questions aiming the problem of research is 11 . Based on the sub-problems, the questions were prepared in an attempt to identify the thoughts of parents. 
In the questionnaire developed in line with the sub-problem questions, 5 questions were asked in order to scrutinize the sampling structure. They were prepared in order to identify "the gender, age and educational backgrounds of the parents of children aged 4-6".

A total of 8 questions were asked for the identification of "Thoughts and Behaviors of Parents towards Their Children's (aged 4-6) Engagement in Music in Daily Life". Then, 3 questions were asked in an attempt to address the Approval of Parents in Supporting Their Children's (aged 4-6) Tendency in Music, and to support sub-problems.

Table 1. Parent Profiles of Children Aged 4-6 according to their gender

\begin{tabular}{lcc}
\hline Gender & n & \% \\
\hline Father & 62 & 41,3 \\
Mother & 88 & 58,7 \\
\hline Total & $\mathbf{1 5 0}$ & $\mathbf{1 0 0 , 0}$ \\
\hline
\end{tabular}

More than half of the participants consist of mothers. The more time mothers spend with their children, the more effective they become in their education. Therefore, the opinions of mothers are thought to be increasing the value of the findings obtained.

Table 2. Parent Profiles of Children Aged 4-6 according to their ages

\begin{tabular}{lcc}
\hline Age & n & \% \\
\hline 21-25 Age & 2 & 1,3 \\
26-30 Age & 35 & 23,3 \\
31-35 Age & 54 & 36,0 \\
36-40 Age & 25 & 16,7 \\
41-45 Age & 23 & 15,3 \\
Older Than 46 & 11 & 7,3 \\
\hline Total & $\mathbf{1 5 0}$ & $\mathbf{1 0 0 , 0}$ \\
\hline
\end{tabular}

The participants are mostly aged between 31-35, and almost half of them stated to have finished university. When the ages of parents are considered, the majority are found to be middle-aged. Therefore, the findings are regarded as important in terms of reflecting the ideas of middle-aged individuals.

Table 3. Parent Profiles of Children Aged 4-6 according to their education level

\begin{tabular}{lcc}
\hline Educational Status & n & \% \\
\hline Elementary School & 14 & 9,3 \\
Secondary School & 18 & 12,0 \\
High School & 44 & 29,3 \\
University & 63 & 42,0 \\
Master Degree & 10 & 6,7 \\
PhD & 1 & 0,7 \\
\hline Total & $\mathbf{1 5 0}$ & $\mathbf{1 0 0 , 0}$ \\
\hline
\end{tabular}

Majority of the participants consist of parents who are university graduates. It is found that almost half of the participants are well-educated when those who completed master and PhD degrees are included in this group.

Table 4. Distribution of Children aged 4-6 according to their genders

\begin{tabular}{|c|c|c|}
\hline $\begin{array}{l}\text { Gender and Age groups of } \\
\text { Children aged 4-6 }\end{array}$ & $\mathbf{n}$ & $\%$ \\
\hline Female & 72 & 48,0 \\
\hline Male & 78 & 52,8 \\
\hline Total & 150 & 100,0 \\
\hline 4-Year-Old & 42 & 28,0 \\
\hline 5-Year-Old & 63 & 42,0 \\
\hline 6-Year-Old & 45 & 30,0 \\
\hline Total & 150 & 100,0 \\
\hline
\end{tabular}

It is understood that almost half of the children consist of female and the other half of males. According to the data obtained from the Table above, it can be suggested that it reveals the common views on female and male children. When the age groups are taken into consideration, it occurs that the data have been mostly obtained from the group of 5-year-olds. According to this, the collected data reflect the common opinion of parents of both male and female children.

\section{Results}

In this part of the study, the following question has been sought for an answer: "What are the thoughts and behaviors of parents on their 4-6-year-old children's interest in music in their daily lives?" 
Table 5. Thoughts and Behaviors of Parents on Their 4-6-year-old Children's Interest in Music in Their Daily Lives

\begin{tabular}{|c|c|c|c|c|c|c|c|c|c|c|}
\hline \multirow{2}{*}{$\begin{array}{l}\text { Frequency } \\
\text { Parent } \\
\text { Behavior }\end{array}$} & \multicolumn{2}{|c|}{ Always } & \multicolumn{2}{|c|}{ Frequently } & \multicolumn{2}{|c|}{ Occasionally } & \multicolumn{2}{|c|}{ Rarely } & \multicolumn{2}{|c|}{ Never } \\
\hline & $\mathbf{n}$ & $\%$ & $\mathbf{n}$ & $\%$ & $\mathbf{n}$ & $\%$ & $\mathbf{n}$ & $\%$ & $\mathbf{n}$ & $\%$ \\
\hline Have their unborn baby listen to music & 13 & 8,7 & 26 & 17,3 & 40 & 26,7 & 35 & 23,3 & 36 & 24,0 \\
\hline Have their children listen to appropriate songs at home & 18 & 12,0 & 35 & 23,3 & 59 & 39,3 & 24 & 16,0 & 14 & 9,3 \\
\hline Listen to music with their children & 14 & 9,3 & 54 & 36,0 & 43 & 28,7 & 32 & 21,3 & 7 & 4,7 \\
\hline Encourage their children to listen to music & 24 & 16,0 & 45 & 30,0 & 42 & 28,0 & 27 & 18,0 & 12 & 8,0 \\
\hline Encourage their children to sing & 13 & 8,7 & 42 & 28,0 & 41 & 27,3 & 40 & 26,7 & 14 & 9,3 \\
\hline Encourage their children to play an i & 17 & 11,3 & 21 & 14,0 & 56 & 37,3 & 37 & 24,7 & 19 & 12,7 \\
\hline Attend to concerts, performances etc. with their ch & 10 & 6,7 & 20 & 13,3 & 55 & 36,7 & 37 & 24,7 & 21 & 14,0 \\
\hline Approve their children's choice of music as a profession & 19 & 12,7 & 15 & 10,0 & 32 & 21,3 & 46 & 30,7 & 38 & 25,3 \\
\hline
\end{tabular}

Data in the third table reveal that the answers are not prominently centered upon one or several options, but rather distributed in similar proportions. It is also indicated that the options rather focus on negative thoughts. Therefore, it is figured that the parents occasionally follow the thought and behavior of having the unborn child listen to songs, having their children listen to appropriate songs, attending concerts or performances with them, and encouraging them to play an instrument; they frequently follow the thought and behavior of listening to music with their children, encouraging them to listen to music, and to sing; and they rarely follow the thought and behavior of approving their children's choice of music as a profession, with an intensity of less than half.

There are also parents who developed positive behaviors regarding music. The proportion of parents who chose "Frequently" and "Always" for the options "have their unborn baby listen to music", "have their children listen to appropriate songs at home", "encourage their children to sing", "attend to concerts, performances etc. with their children" and "approve their children's choice of music as a profession" is approximately 20\%-35\%. This proportion increases up to $36 \%$ when it comes to "listening to music with their children" and "encouraging their children to listen to music". According to this, it can be concluded that the parents rather display the behavior of listening to music together with their children, and motivating their children to listen to music.

Table 6. How Supportive are the Parents of Children Aged 4-6 in terms of Encouraging Their Children's Propensity for Music?

\begin{tabular}{lcccc}
\hline & \multicolumn{2}{c}{ Yes } & \multicolumn{2}{c}{ No } \\
& n & \% & n & \% \\
\hline $\begin{array}{l}\text { Child's Special Engagement in Music other } \\
\text { than the Musical Education Offered at School }\end{array}$ & 20 & 13,3 & 130 & 86,7 \\
Possession of a Musical Instrument at Home & 60 & 40,0 & 90 & 60,0 \\
Parents' Willingness for Their Children's & 96 & 64,0 & 54 & 36,0 \\
Engagement in Musical Activities as a Hobby & & & &
\end{tabular}

In Table 6, it can be observed that the number of children who are engaged in musical activities other than the musical education offered at school are rather low. When we look at the possession of a musical instrument at home, there is a slight increase in the rate of children. It goes even higher when it comes to the parents' willingness for their children's engagement in musical activities. The table above indicates that the parents project a positive approach towards their children's propensity in music. Even though the parents are supportive in terms of their children's engagement in musical activities, the proportion of children aged 4-6, who take private music education, is low. The findings in Table 5 are in parallel with the findings displayed in Table $6.12 .7 \%$ of the parents chose "always" for the option of "approving their children's choice of music as a profession". The proportion of choosing "yes" for "child's special engagement in music other than the musical education offered at school" is $13.3 \%$. These two percentages reveal the proportion of parents who support their children's willingness to choose music as a profession. Based on this, it is figured that the parents are not supportive enough in terms of motivating their children, aged 4-6, for music.

\section{Discussion}

Purpose of this study is to identify the thoughts and behaviors of parents on motivating their children aged 4-6 for music, where the collected data revealed the following results:

Participants of the questionnaire mostly consist of mothers; and when their distribution in terms of age is analyzed, it is figured that they are mostly parents between the ages of 31-35. When these parents' distribution according to their education level is analyzed, it can be observed that almost half of them are university graduates.

When children's distribution according to their gender is analyzed, it is figured that they are divided almost equally, with the males having a slightly higher number.

Opinions of parents revealed that those who have the unborn baby listen to music correspond to a rather low 
proportion. It is concluded that the parents do not have an adequate knowledge or awareness on the importance of having the unborn baby listen to music; and that they are not aware of the relevant scientific studies conducted. It is also figured that only $12 \%$ of the parents have their children listen to appropriate songs at home. This proportion may seem extremely low when the ideas of musical scholars are considered; such as Suzuki, Orff or Kodaly, on the proposition that every child must receive musical education starting at an early age, or even in their mothers' wombs. This is thought to derive from the wrong choices by parents who do not have sufficient knowledge on children's music. When the distribution of parents according to their status of listening to music with their children is analyzed, it is understood that even the proportion of parents choosing the option of "frequently" which is at the highest level, is still rather low. Listening to music can be the quality time the parents spend with their children, and it may provide an opportunity for the occurrence of a cultural exchange. These times must be regarded as periods that enhances communication between the parent and the child. This small proportion indicates the rarity of the musical time shared between the parents and the children.

When the distribution of parents who encourage their children to listen to music is analyzed, the highest proportion is observed at the option of "frequently" by $30 \%$. This indicates that only a small proportion encourage their children to listen to music. It is believed that parents must pay more attention regarding this issue. Additionally, proportion of those who encourage their children to sing and play an instrument turned out to be rather low, as well.

Having the children aged 4-6 to sing the songs taught by their teachers or parents is easier than having them play an instrument. It is concluded that playing an instrument is not encouraged enough as a result of being more difficult and costly. When the distribution of parents according to their attendance to activities such as concerts or performances with their children is analyzed, the highest proportion is found to be in the option of "occasionally" which is $36.7 \%$. This proportion reveals that they rarely carry out such activities which could be regarded as quality time, and that they do not benefit from these cultural atmospheres enough. The parents have been found to not allocate adequate time for this issue. When the distribution of parents according to the approval of their children's choice of music as a profession, the highest proportions are found to have chosen the option of "rarely" with $30.7 \%$ and "never" with $30 \%$. When viewed from this aspect, it can be concluded that they generally do not approve their children's choice of music as a profession.

When the status of children's special engagement in music other than the musical education offered at school is reviewed, it is figured that 20 of them said "Yes" corresponding to $13.3 \%$; while 130 of them said "No" corresponding to $86.7 \%$. The reason for such a distribution is thought to derive from the expensive course fees and private lesson costs. Because, when the parents' willingness for their children's engagement in music as a hobby is analyzed, 96 of them are found to be in favor of the idea, corresponding to $64 \%$. When the distribution of parents' possession of a musical instrument at home is scrutinized, it is figured that 60 of the participants chose "Yes" corresponding to $40 \%$; while 90 of them said "No" with $60 \%$.

In conclusion, it can be suggested that even though the parents encourage their children to listen to music, sing and engage in musical activities as a hobby, they are not in favor of the idea of their children choosing music as a profession.

In light of these opinions, it is concluded that; parents must encourage their children to listen to music more, raise consciousness on musical education by means of attending musical education classes or seminars, and buy affordable instruments in line with their budgets; parents whose children are willing, interested and talented in the field of music must be informed by the music or preschool teacher, and they must make an effort to find suitable environments where their children can sing or play instruments; informing these parents on the potentiality that encouraging their children to choose music as a profession in the future may contribute to their cultural development and professional choices and offer new opportunities; parents' skills on choosing songs suitable for their preschooler children must be measured and necessary trainings or conferences must be provided in order to eliminate these deficiencies, and attendance of parents to the activities such as concerts or performances with their children will contribute to their cultural developments.

\section{References}

Arslan, A. (2003). Importance of music in early childhood and song teaching. New Approaches in Development and Education. edt. Müzeyyen Sevinç. İstanbul: Morpa Kültür Publishing

Eskioğolu, I. (2003). The effects of music education on child development. Music Symposium in the $80^{\text {th }}$ Year of Our Republic, 30-31 October 2003, İnönü University, Malatya Presentations, 116-123.

Gönciu, Ö. İ. (2002). Impacts of music education on the musical sound and auditory perception developments of preschool children aged 4-6. Unpublished Doctoral Thesis. Gazi University, Graduate School of Science. 
Göncü, Ö. İ. (2016). Impacts of music education on the musical sound and auditory perception development of preschool children aged 4-6. Abant İzzet Baysal University Faculty of Education Journal, 16(Silkroad Special Issue), 2382-2392.

Kara, M., \& Pirgon, Y. (2013). Analysis of Suzuki Violin School Method in Terms of Target Behaviors. Journal of Research in Education and Teaching, 2(1).

Kasap, T. B. (2005). Suzuki school method. Journal of Inönü University Faculty of Education, 6(9), 115-128.

Öz, B. N. (2001). Importance of mucis education in the cultural development of human. Journal of Uludağ University Faculty of Education, 14(1).

Özeke, S. (2017). A music teaching method for preschool children and its impacts on child development: Sample of Music Together Sample. Journal of Human Sciences, 14(2).

Schlaug, G., Norton, A., Overy, K., \& Winner, E. (2005). Effects of music training on the child's brain and cognitive development. New York Academy of Sciences, 1060(1), 219-230. https://doi.org/10.1196/annals.1360.015

Şendurur, Y., \& Barış, D. (2002). Music education and cognitive achievement of children. Journal of Gazi University Faculty of Gazi Education, 22(1), 165-174. https://okul.com.tr/anaokulu retrieved: 22.06.2018.

Sun, M., \& Seyrek, H. (1993). Music in preschool education. İzmir: Mey Publishing.

Temiz, E. (2007). The effect of voice training on 35-40 months children in three years age in pre-school education on musical sound development of hearing loss and hearing lossless children. Unpublished Doctoral Thesis, Gazi University.

Uçan, A. (1997). Main concepts - principles - approaches in music education. Ankara: Müzik Ansiklopedisi Publishing.

\section{Copyrights}

Copyright for this article is retained by the author(s), with first publication rights granted to the journal.

This is an open-access article distributed under the terms and conditions of the Creative Commons Attribution license which permits unrestricted use, distribution, and reproduction in any medium, provided the original work is properly cited. 